\title{
Research of the University Teaching Interaction Behavior Characteristics in the Smart Classroom
}

\author{
Jiangbo Shu, Min Zhi, and Qianqian Hu
}

\begin{abstract}
Recently, the application of smart classroom has provided a place for teaching practice innovation of the front-lines teachers in higher education. Interaction is the core of smart classroom and the direct reflection of teaching effect. Exploring the characteristics of university classroom teaching interaction will play an important guiding role in improving teaching practice. Based on the existing classroom teaching interactive coding system, this paper put forward SCIAS coding system, and took starC smart classroom which is developed by Central China Normal University as research scene, selected several classroom videos of excellent teaching cases in this environment as research objects, SCIAS was utilized to analyze the class records from five aspects: the classroom teaching atmosphere, the classroom teaching structure, the teacher-student talk interaction, the student-student talk interaction, the interaction between human and technology. Findings from the research provide an indictation that university classroom atmosphere is easy and harmonious, students' subjectivity has been concerned, teacher can interact with students frequently and cooperative learning between group members is outstanding, human-machine interaction accounts for a higher proportion and the application of technology in different classes has obvious differences in the smart classroom.
\end{abstract}

Index Terms-Smart classroom, SCIAS coding system, teaching interaction.

\section{INTRODUCTION}

With rapid development of education informationization, the deep integration of information technology and education leads and accelerates the changes of classroom teaching environment, smart classroom is a new type of classroom environment generated in the context of this educational situation [1]. Interaction is the central link of teaching in such technology-rich classroom environment [2], its features such as auto-sensing, recognition, interconnection and device portability fully meet learner's requirements for strong interaction, therefore, classroom interaction in the smart classroom has aroused widespread concern of researchers [3].

Interaction is at the core of classroom teaching [4], only

Manuscript received December 19, 2017; revised May 28, 2018. This research was partially funded by the National Key Research and Development Program of China (No.2017YFB1401301), the Fundamental Research Funds for the Central Universities (No.CCNU17TS0002), the National Natural Science Foundation of China under Grant (No.61505064, No.61702211), the Project of the Program for National Key Technology Research and Development Program (2014BAH22F01).

The authors are with National Engineering Research Center for E-Learning, Central China Normal University, Wuhan, Hubei 430079 China (e-mail: shujiangbo@mail.ccnu.edu.cn, 2311230078@qq.com, 972455086@qq.com). through interaction can learners achieve sense-making in classroom teaching [5]. At present, the study of classroom teaching interaction under the smart environment is mainly focused on two aspects in China: the first is the study of the interaction theory, representatives are Huang, Chen, Li etc [6]-[8]; the second is to use the classroom observation tools to analyze the interaction of classroom teaching from the empirical perspective. For instance, Wang recorded and analyzed the interactive process of 54 English classes in the smart classroom based on CIOSM, the study found that the technology-rich classroom environment had better enhanced and enriched interaction frequency, interaction subjects and interaction content [9]. Zhang used quasi-experimental method to compare and analyze the elementary mathematics lesson of "Fan-shaped Statistics Chart" between the simple multimedia environment and the smart environment, finding that teaching in smart classroom environment was more conducive to students' subjectivity and students' enthusiasm for participation [10].

Smart classroom, as a new form of developing future classroom, the analysis and description of classroom teaching interaction in the smart classroom are based on logical deduction and reasoning in China mostly, there is relatively rare research based on fieldwork and quantitative analysis of data and the research is focused on the classrooms of primary and secondary schools. With the application of smart classroom, smart classrooms are entering into institutions of higher education gradually, for this environment, the front-lines teachers in universities are trying to carry out diversified teaching practice and innovation, however, in this environment, what on earth the classroom teaching atmosphere and classroom structure are about? How about the interactive forms and relationships of teachers and students? What are the main functions of rich technology in the classroom? These problems are rarely explored by scholars at present. In this context, based on summarizing the existing teaching behavior quantification tools, the paper improved the quantitative tool of classroom teaching and put forward SCIAS which is the abbreviation of Smart Classroom-Based Interaction Analysis System, attempting to utilize SCIAS to record and analyze the interactive process of university classroom teaching in the smart classroom to understand the features of technology-rich classroom teaching interaction and provide reference and guidance for the practice of more university classroom teaching in this environment.

\section{INTERACTIVE ANALYSIS CODING SYSTEM}

Flanders Interaction Analysis System (FIAS) is a typical 
mature quantitative analysis tool for classroom teaching [11]. The use of information technology has grown up to an important part of classroom teaching today, but this kind of interaction behavior can't be reflected in FIAS, which is treated as silence merely. From the perspective of new curriculum reform and application of information technology, $\mathrm{Gu}$ improved FIAS and proposed Information Technology-Based Interaction Analysis System (ITIAS) [12], which enriches students' talk behavior, subdivides "silence" and increases the interaction behaviors between human and technology. However, ITIAS is proposed at the beginning of the introduction of information technology in the classroom. The classification of technology talk is talked in generalities, which can't reflect the purpose of teacher/student interaction with technology. The great progress of technology has led to significant changes in teaching environment and teaching methods, and classroom teaching environment is developing from simple multimedia classroom to smart classroom. Han improved the coding system of ITIAS and proposed One to One Techo-Based Interaction Analysis System (OOTIAS) [13]. But the coding system only expands the coding categories of the technology, and the explanation of the interaction between human and technology is ambiguous.
Besides, Zhang firstly proposed the classroom interaction analysis coding system under the smart environment (IFIAS) to improve FIAS [10], the coding system completely changed the classification of FIAS coding in teacher talk, so it can't describe the verbal interaction between teachers and students very well.

For the research purpose, IFIAS can be better used in the analysis of smart classroom teaching with information technology support, it was adjusted and perfected in the paper, a classroom interactive analysis system based on the smart classroom was formed finally, which is shown in Table I. The improved aspects are as follows: (1) on the aspect of teacher's talking, keep the code categories of FIAS such as "accept feelings", "encourage and praise", "adopt comments", "criticizing" and so on. Its purpose is to retain traditional analysis function of FIAS, for instance, the teacher's teaching style can be analyzed according to the ratio of indirect and direct influence of teacher. (2) on the aspect of technology talk, improvements are made based on the major interaction between people and technology in today's smart classroom environment, and the meaning of the code is expressed in a clear way, which is convenient for the division of behavior in actual classroom observation.

TABLE I: SMART CLASSROOM-BASED INTERACTION ANALYSIS SYSTEM (SCIAS)

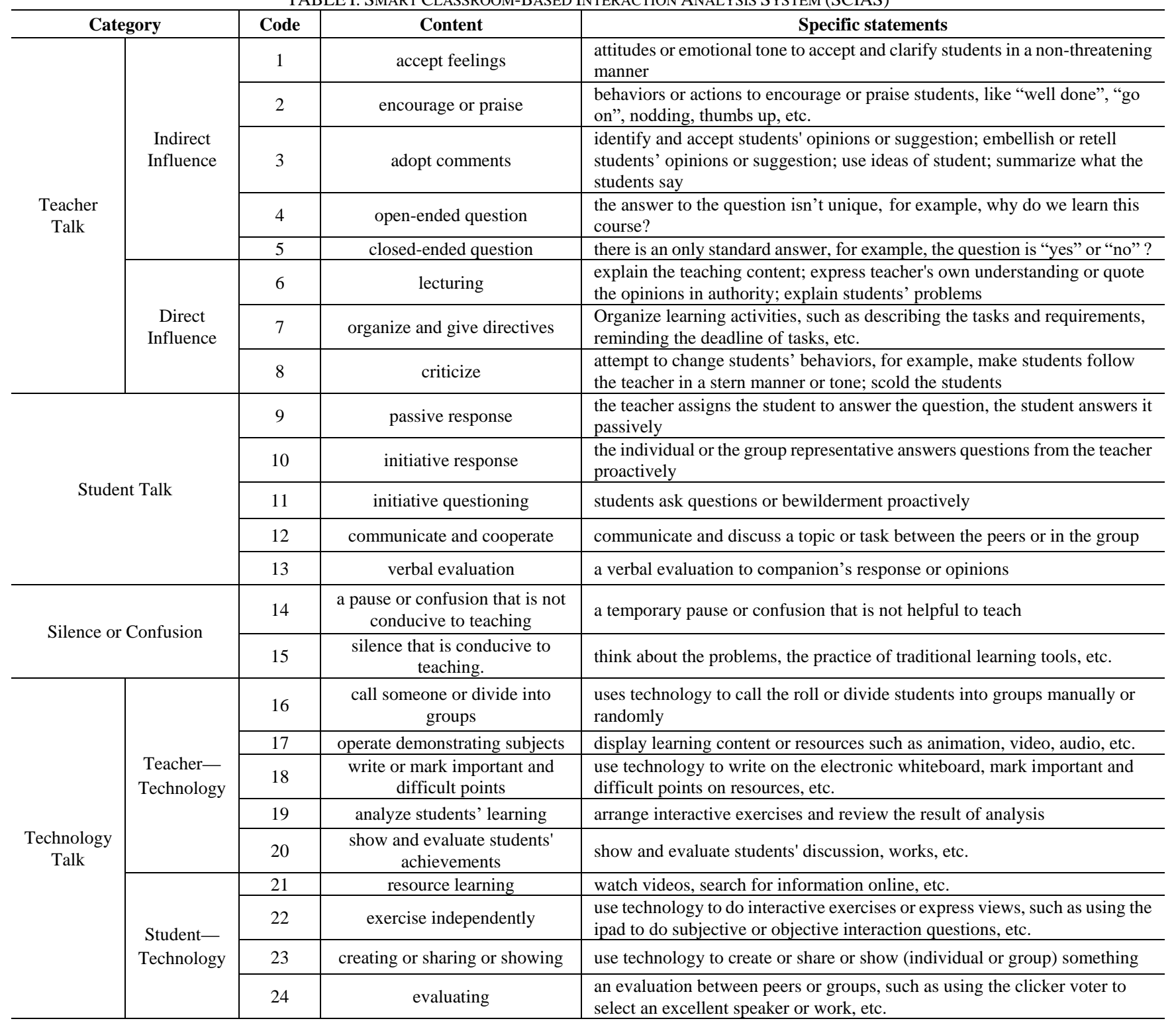




\section{RESEARCH SAMPLES AND DATA PREPARATION}

At present, the application of starC smart classroom has covered primary school, middle school and university, it has been widely spread and used in Central China Normal University (CCNU) for a long time. In the paper, eight classroom videos of the excellent teaching cases of CCNU were selected as research samples and the videos came from the starC recording system in the smart classroom, which are shown in Table II.

TABLE II: CLASSROOM RECORD VIDEO SAMPLES

\begin{tabular}{|c|c|c|c|}
\hline Number & Course & Content & Duration \\
\hline Cv1 & $\begin{array}{c}\text { Introduction to } \\
\text { Maoism and } \\
\text { Chinese-featured } \\
\text { Socialism Ideology } \\
\text { Applied Technology of } \\
\text { Database }\end{array}$ & Preface & $46^{\prime} 25^{\prime \prime}$ \\
\hline Cv2 & General Psychology & $\begin{array}{l}\text { Perception } \\
\text { consciousness }\end{array}$ & $50^{\prime} 2^{\prime \prime}$ \\
\hline Cv3 & $\begin{array}{l}\text { The Principles of } \\
\text { Database System }\end{array}$ & SQL data query & $45^{\prime} 29^{\prime \prime}$ \\
\hline $\mathrm{Cv} 4$ & Chemistry-Pedagogy & $\begin{array}{c}\text { Chemical } \\
\text { teaching design }\end{array}$ & $42^{\prime} 5^{\prime \prime}$ \\
\hline Cv5 & $\begin{array}{l}\text { Design of Biology } \\
\text { Teaching in Middle } \\
\text { School }\end{array}$ & $\begin{array}{l}\text { Learner } \\
\text { analysis }\end{array}$ & $48^{\prime} 36^{\prime \prime}$ \\
\hline Cv6 & $\begin{array}{l}\text { Moral Cultivation and } \\
\text { Legal Basis }\end{array}$ & $\begin{array}{l}\text { Ideal belief } \\
\text { theory }\end{array}$ & $47^{\prime} 14^{\prime \prime}$ \\
\hline Cv7 & University English & $\begin{array}{l}\text { Hobbies and } \\
\text { interests }\end{array}$ & $45^{\prime} 28^{\prime \prime}$ \\
\hline Cv8 & $\begin{array}{c}\text { The Principles of } \\
\text { Marxism }\end{array}$ & $\begin{array}{l}\text { What is } \\
\text { philosophy }\end{array}$ & $43^{\prime} 42^{\prime \prime}$ \\
\hline
\end{tabular}

According to the code in Table I, the method of time sampling (every 3 seconds) were used to record and encode classroom behaviors of eight samples, eight record sheets of classroom observation were formed at the same time. Due to the complexity and overlap of actual teaching interaction acts, some interactive behaviors were difficult to judge during encoding. Thus, the following encoding rules are made: 1) if there are multiple kinds of interaction within 3 seconds, trying to record all the behaviors as much as possible, and choosing the interaction behavior different from that occurred within the previous 3 seconds. 2) when students actively share their cooperation results after the group communication, if a representative is supposed to make an oral speech, the code is classified as the number 10. If the results are showed and shared by the media, the code is considered to be 23. 3) if teachers use technology to show resources without explanation, the code is classified as 17 . If teachers use technology as a means to help explain teaching content and the behavior is primarily based on lecturing, the code is 6 . Other teaching activities carried out by technology are classified as technology talk. 4) if students complete the exercise with traditional instruments such as paper and pen, the code is 15 . If students complete the exercise using the technique, this situation is classified as 22 .

The way that the study deals with the code of every classroom observation record sheet is as follows: each code is combined with the previous code and the next code to form "order pair", the codes were used twice except for the first and the last code, the 24 types of code in Table I are used as the transverse and longitudinal axis label to form a $24 \times 24$ migration matrix and the number of "order pair" is filled into the matrix after calculating, which is shown in Table III. In order to express easily, the element that is combined with row and column is defined as cell $(i, j)$, the sum of each column is $\operatorname{row}(i)=\sum_{j=1}^{24} \operatorname{cell}(i, j)$, the sum of each row is $\operatorname{col}(j)=\sum_{i=1}^{24} \operatorname{row}(i)$, the sum of all the elements in the matrix is total $=\sum_{i=1}^{24} \sum_{j=1}^{24} \operatorname{cell}(i, j)$, the specific calculation formulas are shown in Table IV, which is the foundation of the subsequent analysis of the paper.

\section{TEACHING INTERACTION ANALYTICS}

\section{A. Analysis of Emotional Atmosphere in Class}

In the migration matrix formed by the SCIAS coding system, the cross-region of 1-3 rows and 1-3 columns is positive grid. If the number of "order-pair" in this area is intensive, it can represent that teachers and students are more harmonious in emotional communication, which is the performance of positive integration. The cross-region of 8-9 rows and 7-8 columns is defective grid, if the number of "order-pair" in this area is intensive, which reflects the emotional communication between teachers and students is not very well. In the paper, the ratio of positive grid and the ratio of defective grid were defined as P_G, D_G separately, $P_{-} G=\sum_{i=1}^{3} \sum_{j=1}^{3} \operatorname{cell}(i, j)$ and $D_{-} G=\sum_{i=8}^{9} \sum_{j=7}^{8} \operatorname{cell}(i, j)$

As is shown in Fig. 1, the P_G of six samples is between $2 \%$ and $2.5 \%$, the P_G of sample Cv4 and Cv5 is more than 5\%, integrated with the class video, teachers and students interacted frequently in these two classes, teachers gave more encouragement after the student's response and continued to ask questions based on the student's answer. The D_G of eight classes are all zero, the $P_{-} G$ is much higher than $D_{-} G$. It shows that teachers and students have a harmonious relationship in the smart classroom, which is conducive to classroom teaching.

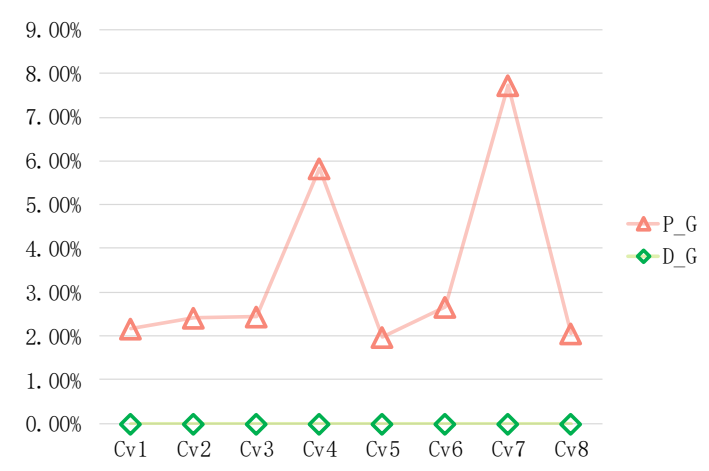

Fig. 1. Analysis of classroom atmosphere.

\section{B. Analysis of Classroom Teaching Structure}

SCIAS divides classroom behavior into four categories: teacher talk, student talk, silence or confusion and technology talk. The proportion of four kinds of behaviors in class can reflect the structure of classroom teaching. The distribution of four kinds of behavior in the eight sample classes is shown in 
TABLE III: MigRATION MATRIX EXAMPLE

\begin{tabular}{|c|c|c|c|c|c|c|c|c|c|c|}
\hline & & \multicolumn{3}{|c|}{ Teacher Talk } & \multicolumn{2}{|c|}{ Student Talk } & \multicolumn{2}{|c|}{$\begin{array}{l}\text { Silence or } \\
\text { Confusion }\end{array}$} & \multicolumn{2}{|c|}{ Technology Talk } \\
\hline & & 1 & $\ldots$ & 8 & 9 & $\ldots$ & 14 & 15 & 16 & $\ldots$ \\
\hline \multirow{3}{*}{ Teacher Talk } & 1 & 6 & $\ldots$ & 0 & 5 & $\ldots$ & 3 & 10 & 2 & $\ldots$ \\
\hline & $\ldots$ & $\ldots$ & $\ldots$ & $\ldots$ & $\ldots$ & $\ldots$ & $\cdots$ & $\ldots$ & $\ldots$ & $\ldots$ \\
\hline & 8 & 0 & $\ldots$ & 0 & 0 & $\ldots$ & 0 & 0 & 0 & $\ldots$ \\
\hline \multirow{2}{*}{ Student Talk } & 9 & 3 & $\ldots$ & 0 & 10 & $\ldots$ & 0 & 3 & 2 & $\ldots$ \\
\hline & $\ldots$ & $\ldots$ & $\ldots$ & $\ldots$ & $\ldots$ & $\ldots$ & $\ldots$ & $\ldots$ & $\ldots$ & $\ldots$ \\
\hline \multirow{2}{*}{$\begin{array}{l}\text { Silence or } \\
\text { Confusion }\end{array}$} & 14 & 1 & $\ldots$ & 0 & 2 & $\ldots$ & 5 & 0 & 6 & $\ldots$ \\
\hline & 15 & 0 & $\ldots$ & 0 & 0 & $\ldots$ & 0 & 0 & 0 & $\ldots$ \\
\hline \multirow{2}{*}{ Technology Talk } & 16 & 0 & $\ldots$ & 0 & 5 & $\ldots$ & 10 & 0 & 20 & .. \\
\hline & $\ldots$ &. & $\ldots$ & $\ldots$ & .. & $\ldots$ & ... & $\ldots$ & $\ldots$ & .. \\
\hline
\end{tabular}

TABLE IV: CALCULATION FORMULA OF RATIO

\begin{tabular}{|c|c|c|c|}
\hline Verbal behavior ratio & Formula & Verbal behavior ratio & Formula \\
\hline teacher talk ratio(T_R) & $\sum_{i=1}^{8} \operatorname{row}(i) /$ total & student talk ratio(S_R) & $\sum_{i=9}^{13} \operatorname{row}(i) /$ total \\
\hline $\begin{array}{l}\text { indirect and direct influence } \\
\text { ratio(T_R(i_d }))\end{array}$ & $\sum_{i=1}^{5} \operatorname{row}(i) / \sum_{i=6}^{8} \operatorname{row}(i)$ & $\begin{array}{l}\text { passive response } \\
\text { ratio(S_P) }\end{array}$ & $\operatorname{row}(9) / \sum_{i=9}^{13} \operatorname{row}(i)$ \\
\hline asking questions ratio(T_Q) & $\sum_{i=4}^{5} \operatorname{row}(i) / \sum_{i=1}^{8} \operatorname{row}(i)$ & initiative response(S_A) & $\operatorname{row}(10) / \sum_{i=9}^{13} \operatorname{row}(i)$ \\
\hline $\begin{array}{l}\text { open-ended and closed-ended } \\
\text { questions ratio(T_R(c_o }) \text {. }\end{array}$ & ow(4) & $\begin{array}{l}\text { initiative questioning } \\
\text { ratio(S_Q) }\end{array}$ & $\operatorname{row}(11) / \sum_{i=9}^{13} \operatorname{row}(11)$ \\
\hline technology talk ratio(TS_R) & (i)/total & $\begin{array}{l}\text { communicating and } \\
\text { cooperating ratio(S_D) }\end{array}$ & $\operatorname{row}(12) /$ total \\
\hline $\begin{array}{l}\text { teacher-technology } \\
\text { ratio(TT_R) }\end{array}$ & $\sum_{i=15}^{20} \operatorname{row}(i) / \sum_{i=15}^{24} \operatorname{row}(i)$ & $\begin{array}{l}\text { verbal evaluation } \\
\text { ratio(S_E) }\end{array}$ & $\operatorname{row}(13) /$ total \\
\hline $\begin{array}{l}\text { calling someone or dividing } \\
\text { into groups ratio(TT(n_g)) }\end{array}$ & $\operatorname{row}(16) / \sum_{i=15}^{20} \operatorname{row}(i)$ & $\begin{array}{l}\text { student-technology } \\
\quad \text { ratio(ST_R) }\end{array}$ & $\sum_{i=20}^{24} \operatorname{row}(i) / \sum_{i=15}^{24} \operatorname{row}(i)$ \\
\hline $\begin{array}{l}\text { operating demonstrating } \\
\text { subjects ratio(TT(o_c }))\end{array}$ & $\operatorname{row}(17) / \sum_{i=15}^{20} \operatorname{row}(i)$ & resources learning (ST_L) & $\operatorname{row}(21) / \sum_{i=20}^{24} \operatorname{row}(i)$ \\
\hline $\begin{array}{l}\text { writing or marking important } \\
\text { and difficult points } \\
\left.\text { ratio(TT }\left(\mathrm{w} \_\mathrm{m}\right)\right)\end{array}$ & $\operatorname{row}(18) / \sum_{i=15}^{20} \operatorname{row}(i)$ & $\begin{array}{l}\text { exercising independently } \\
\text { ratio } \\
\text { (ST_P) }\end{array}$ & $\operatorname{row}(22) / \sum_{i=20}^{24} \operatorname{row}(i)$ \\
\hline $\begin{array}{l}\text { analyzing students'learning } \\
\text { ratio(TT_A) }\end{array}$ & $\operatorname{row}(19) / \sum_{i=15}^{20} \operatorname{row}(i)$ & $\begin{array}{l}\text { creating or sharing or } \\
\text { showing } \\
\left(\mathrm{ST}\left(\mathrm{s} \_\mathrm{s}\right)\right)\end{array}$ & $\operatorname{row}(23) / \sum_{i=20}^{24} \operatorname{row}(i)$ \\
\hline $\begin{array}{l}\text { showing and evaluating } \\
\text { students' achievements } \\
\text { ratio(TT(s_e) })\end{array}$ & $\operatorname{row}(20) / \sum_{i=15}^{20} \operatorname{row}(i)$ & evaluating ratio(ST_E) & $\operatorname{row}(24) / \sum_{i=20}^{24} \operatorname{row}(i)$ \\
\hline \multicolumn{2}{|c|}{ silence or confusion ratio(C_R) } & \multicolumn{2}{|c|}{$\sum_{i=14}^{15} \operatorname{row}(i) /$ total } \\
\hline
\end{tabular}

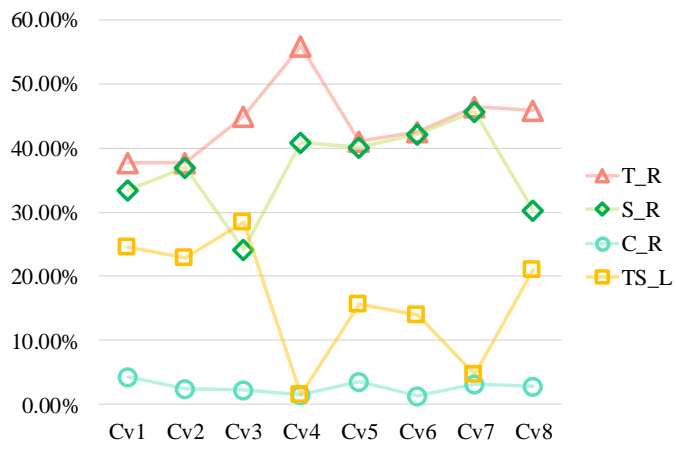

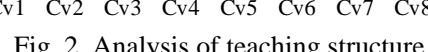

Fig. 2 the T_R and S_R in 5 classes are close to $1: 1$, and the $T \_R$ of the remaining three classes is higher than $S \_R$. Dating back to classroom videos, the teacher in the class of $\mathrm{Cv} 3, \mathrm{Cv} 4$ and $\mathrm{Cv} 8$ gave more explanation, and the number of "lecturing" of teacher talk is 303,284 and 288 respectively in these three matrixes. In general, in the smart classroom, most teachers in universities and colleges have reformed their conventional teaching mode from the traditional teacher-centered knowledge-feeding pattern to the new student-centered teaching mode. The $\mathrm{C} \_\mathrm{R}$ of eight classes is lower than five percent, it can reflect that classroom instruction efficiency has been improved obviously from the side. Although students are given more initiative in the class, which doesn't create an atmosphere of confusion or dreariness and teachers can carry out teaching activities reasonably. Besides, the proportion of technology talk behaviors is high, but there are obvious differences of technology talk ratio among 8 samples. The TS_R of some sample classes is much lower, such as $\mathrm{Cv} 4$ and $\mathrm{Cv} 7$, but the $\mathrm{T} \_\mathrm{R}$ of $\mathrm{Cv} 7$ is close to $\mathrm{S} \_\mathrm{R}$, which indicates teachers should use the media on the basis of the course to a certain extent.

\section{Analysis of Teacher-Student Verbal Interaction}

Teacher-student verbal interaction can be analyzed through T_R (i_d), T_Q, T_R (c_o) of teacher talk and S_A, S_P, S_Q of student talk. In SCIAS, teacher talk behaviors are divided into two aspects: indirect influence and direct influence. Teachers have different teaching tendencies and styles, depending on the frequency of two kinds of teaching behaviors which they use. [14]. From Fig. 3(a), the T_R (i_d) is less than one percent except for $\mathrm{Cv} 7$, which shows teachers tend to make direct verbal influence on class and students, combined with classroom videos there were more directive speech behaviors mainly reflected in the organization of students to explore activities. And, the T_Q is not high of eight samples judging from the data, but the $T_{-} R$ (c_o) is less than one percent through the analysis of types of questions that are asked, which shows that university teachers tend to 
use open-ended questions to carry out learning activities of exploration and communication, which is conductive to the communication among students. In student talk, the positivity of students in classroom interaction can be understood by comparing S_A and S_P. From Fig. 3(b), the S_A is much higher than S_P, it shows that students respond actively after proposeing questions by the teacher, which reflects the initiative of students' learning has been made a progress and they participate in teaching more actively in the smart classroom. Besides, the S_Q of six samples is zero, which makes clear that teachers ignore the cultivation of students' critical thinking ability to some extent.

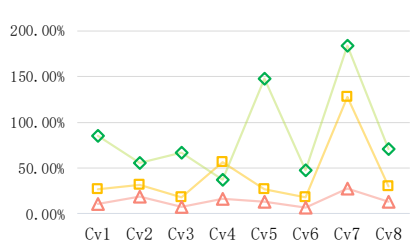

(a) $\square T_{-} L\left(i_{-} d\right) \quad \Delta T_{-} Q \quad \diamond T_{-} L\left(c \_o\right)$

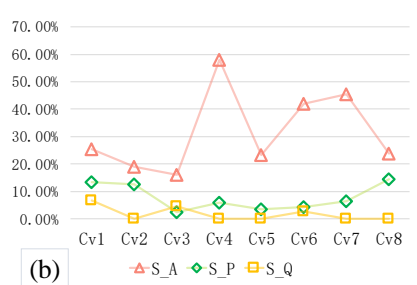

(b) $\triangle S_{-} A \diamond S_{-} P \square S_{-} Q$
Fig. 3. Analysis of teacher-student verbal interaction behavior.

\section{Analysis of Student-Student Verbal Interaction}

Peers verbal interaction can be analyzed through S_D and S_E of student talk. From Fig. 4, the verbal behaviors in which students evaluate peers' response or opinions don't occur in all eight sample classes, student-student verbal interaction mainly embodies communication and cooperation of students. The S_D of seven samples is more than eighteen percent, which accounts for $1 / 5$ of the entire classroom behaviors. Dating back to classroom videos, the open seating arrangement of desks and chairs, the side screens on the wall of smart classroom were found to be helpful for the interaction among students, and the form of discussion was based on group cooperative learning. As for the problem situations created by teachers, students would also cooperate with the existing learning resources in the starC and network resources in addition to the traditional group communication. Students can actively participate in group inquiry and freely expressed their views in the smart classroom. The ideological collision in the process of communication, which is conducive to promote students' deep cognition of the learning content.

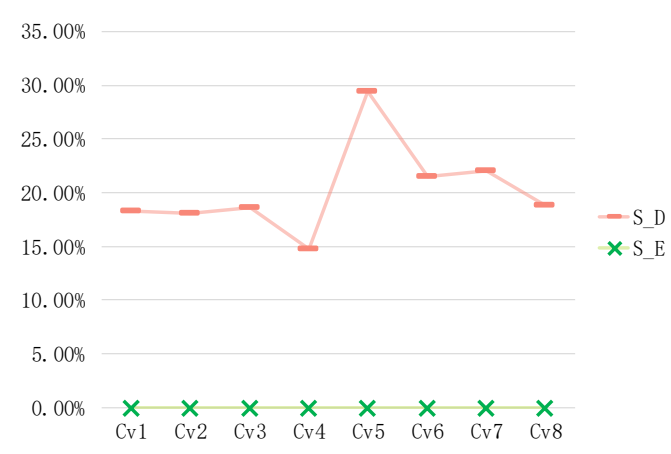

Fig. 4. Analysis of student-student verbal interaction behavior.

\section{E. Analysis of Student-Student Verbal Interaction}

From the analysis of classroom structure, there are some differences in technology talk ratio of eight samples. Whether there is a significant difference in the interaction of teachers-technology and students-technology, a specific analysis of technology talk is needed to explore. In SCIAS, technology talk is divided into two categories: teacher-technology and student-technology. From Fig. 5, the TT_R of seven samples is obviously higher than ST_R. It indicates that teachers have changed the technology usage way of one-way transmission but give more rights to students, so as to students have more opportunities to interact with the media such as studying, practicing, displaying and evaluating with technology. As for $\mathrm{Cv} 4$, with the teaching structure and the classroom video record, the teacher used the method of dialogue to carry out teaching due to the need of the teaching content and the use of technology which was primarily reflected in the teacher's resources demonstration, so the $\mathrm{ST}$ - $\mathrm{R}$ is zero.

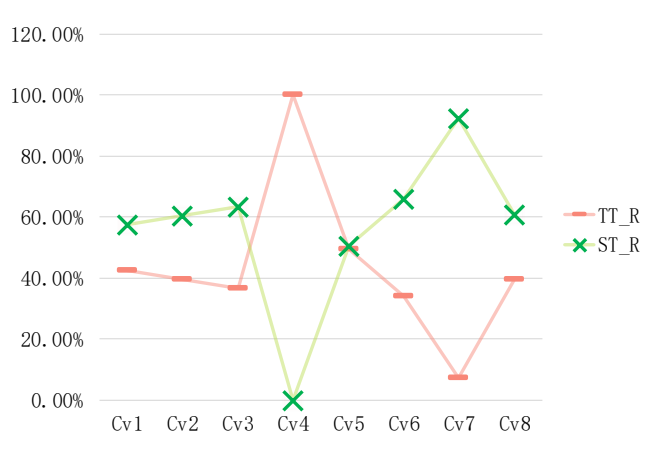

Fig. 5. Overall analysis of teacher/student-technology talk.

To understand the precise interaction aspects of teacher-technology and student-technology, there is a need for further analysis of them. From Fig. 6(a), in teacher-technology talk, the interaction between teacher and technology is basically reflected in demonstrating subjects and showing students' achievements, teachers use 2-3 kinds of technical forms to carry out teaching activities in six sample classes, however the technical forms used in each class are not the same. Besides, there are also some teachers just use technology for resource demonstration, such as Cv4 and Cv7. Generally speaking, university teachers try to use the media to increase interaction with students. Some teachers begin to pay attention to depth of technology application in teaching. In student-technology talk, it can be seen from Fig. 6(b), the interaction between student and technology is chiefly which is reflected in resource learning and independence exercising. The number of behaviors of using technology for resource learning, exercising independently, creating and sharing, evaluating is not the same significantly in different classes, which has a certain relationship with the course content combing the analysis of classroom structure. Therefore, it shows that university teachers don't come into the error of "use technology for technology" in the smart classroom from the side.
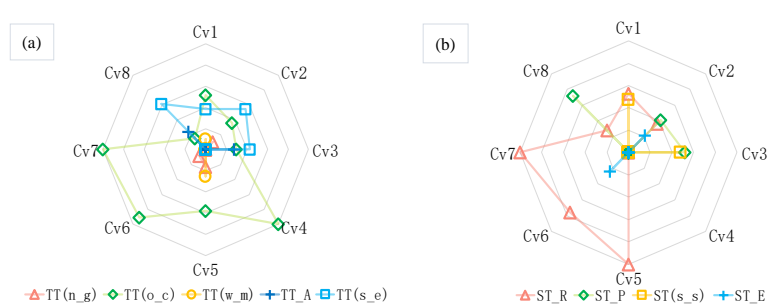

Fig. 6. Specific analysis of teacher/student-technology parole. 


\section{CONCLUSION}

In the paper,we took the starC smart classroom of CCNU as the research scene, and utilized the improved SCIAS coding system to analyze the classroom videos of eight excellent teaching cases in the environment from five aspects. Some characteristics of university classroom teaching interaction in the smart environment are extracted, which are summarized as follows: 1) teachers and students get on well in emotional communication and classroom teaching is in a relaxing and harmonious atmosphere, which fully mobilizes the enthusiasm of students'learning. 2) the characteristics of the teaching structure of "teacher-dominant and student-subject" are reflected and students' subjectivity has been improved. 3) teachers tend to make direct control of students and classes and are good at using open-ended questions to guide students to explore activities, students' communication and initiative response ratio is high. 4) the interaction between peers is outstanding and its form is primarily based on group cooperative learning. 5) the technology talk behaviors are in large proportion, students have more chances to interact with the media. The use of technology has obvious differences in different classes. This research not only provide a more systematic understanding of the interactive features of classroom teaching in higher education but also provide a reflective basis for the teaching practice of teachers. However, whether the quality of university classroom interaction is deep and efficient and what factors can affect the quality of interaction need further verification, so the quality of university classroom interaction in the smart environment will become the focus in the future research.

\section{REFERENCES}

[1] L. Cui and L. Dong, "An empirical study on classroom interaction in middle school - A case of taking mathematics classroom in junior high school," E-Education Research, pp. 123-128, 2017.

[2] W. Chen, X. Ye, and Y. Xu, "Future classroom: Smart learning environment," Journal of Distance Education, pp. 42-49, 2012.

[3] X. Wang, S. Wang, and R. Huang, "Research of primary and middle class observation tools for the smart classroom," E-Education Research, pp. 49-53, 2015.

[4] W. Chen, X. Ye, J. Qin et al., "Future classroom - High interactive learning space," China Educational Technology, pp. 6-13, 2011.

[5] C. Craig, Second Language Classrooms: Research on Teaching and Learning, Cambridge University Press, 1988.
[6] R. Huang, Y. Yang, G. Xiao et al., "The functions of smart classroom in smart learning age," Open Education Research, pp. 22-27, 2012.

[7] D. Wei, X. Ye, and J. Zhang, "Research on the forms and characteristics of interaction of future classroom," E-Education Research, pp. 91-97, 2011.

[8] H. Li and J. Zhang, "The ARS interactive teaching model and its application in the smart classroom," China Educational Technology, pp. 103-109, 2015.

[9] X. Wang, R. Huang, M. Wang et al., "Analysis of classroom interaction in smart classroom in primary and middle schools," E-Education Research, pp. 111-116, 2016.

[10] Y. Zhang, Y. Zhu, Y. Xiao et al., "Research of the teaching interaction behavior characteristics of primary mathematics in the smart classroom," China Educational Technology, pp. 43-48, 2016.

[11] N. Flanders, "Intent, action and feedback: A preparation for teaching," Journal of Teacher Education, vol. 14, pp. 251-260, 1963.

[12] X. Gu and W. Wang, "New exploration of classroom analysis in support of teacher professional development," China Educational Technology, pp.18-21, 2004.

[13] H. Han, D. Wang, and C. Cao, "Analysis and research on the interactive behavior of classroom teaching in the one to one digital environment," E-Education Research, pp. 89-95, 2015.

[14] H. Ning and J. Wu, "Establishment of links between quantitative structure and meaning comprehension," Educational Research, pp. 23-27, 2003

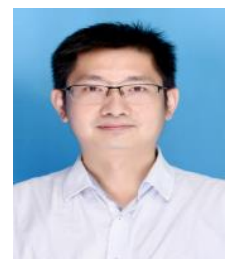

Jiangbo Shu received the B.S. degree in computer science and technology from Central China Normal University, Wuhan, Hubei, China, in 2005 and the M.S. degree in computer software and theory from Central China Normal University, Wuhan, Hubei, China, in 2008 and the doctorate in Chinese information processing from Central China Normal University, Wuhan, Hubei, China, in 2011. From 2011 to 2017, he is an associate professor, and working at the National Engineering Research Center for e-learning, Wuhan, Hubei, China. His research interests include software engineering, computer application technology, cloud computing and big data.

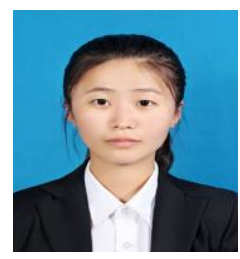

Min Zhi is a master student studying at the National Engineering Research Center for e-learning, Wuhan, Hubei, China. Her research interests including educational technology and teaching behavior analytics.

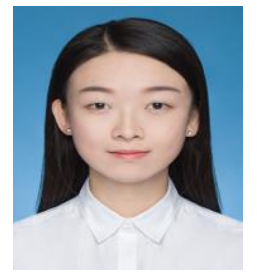

Qianqian Hu is a master student studying at the National Engineering Research Center for e-learning, Wuhan, Hubei, China. Her research interests including educational technology and learning analytics. 